\title{
Is Food More than a Means of Survival? An Overview of the Balkan Prison Systems
}

\author{
Tia Simanovic ${ }^{\mathrm{a}, 1, *}$, Masa Gosev ${ }^{\mathrm{b}, 2,}$ \\ ${ }^{a}$ University of Strathclyde, Glasgow, Scotland \\ ${ }^{b}$ XV Gymnasium, Zagreb, Croatia
}

\begin{abstract}
Food is a versatile national, social, and cultural marker. It represents more than just a means of survival (Stajcic, 2013); it is an expression of identity (Jones, 2017). Food has a symbolic power and carries a sense of community, relays customs, habits, and values. According to Godderis (2006), people "do" food. In institutional settings, such as prisons, often stripped of basic human rights and dignity, food can acquire yet another dimensions. It can become a means to pass time, regain normalcy, and cope with daily hardships. Despite its multifaceted importance, there is a paucity of research on prisoners' diet, with most being done on the US, UK, and Scandinavian prison systems (Smoyer, 2019 Smoyer and Kjaer Minke, 2015).

This article drew from academic and non-academic sources (e.g., government reports, newspaper articles, prison blogs) to provide an overview of the Balkan prison systems through the lens of food. It will present weekly menus from three different countries and discuss alternative ways of accessing food in prisons (i.e., through prison commissary, prison farms, and food packages). It will further demonstrate prisoners' use of food to regain autonomy in the context of multiple deprivations. Lastly, this paper will reflect on the role of food, coffee, and cigarettes in prisoners' socialization, as well as in reiteration of prisoner subculture.
\end{abstract}

Keywords: Balkan prisons, Prison food, Food packages

\section{Introduction}

Research on food mostly comes from sociology, anthropology, and cultural studies, yet Barthes (2012) criticized the contemporary psycho-sociological approach to food merely through eating habits and discussed the

\footnotetext{
*Corresponding author: Tia Simanovic, School of Social Work and Social Policy, Lord Hope Building, 141 St James Road, Glasgow, G4 0LT

Email address: tia.simanovic@strath.ac.uk (Tia Simanovic)

${ }^{1} \mathrm{PhD}$ Candidate with the School of Social Work and Social Policy

${ }^{2}$ High School Senior
} 
inter-relatedness of food and culture. However, the mundanity and omnipresence of food led to its neglect in broader academic research (Stajcic, 2013). The rise of food industry in the second half of the twentieth century gave a new layer of meaning to food and a multiplicity to its concepts (Duda, 2017; Stajcic, 2013). Still, the purely cultural aspect of food as a bonding agent and an insight into society's traditions, beliefs, and practices, is kept at its core (Stajcic, 2013). Despite modernization, the main meal of the day in the Balkan region remained home-made, consumed within the family (Duda, 2017).

\section{The Balkans}

The Balkans is a geo-historical region in the southeastern Europe. It has always had an important strategic value as a direct land route between western Europe and southwestern Asia (Grofelnik, 2014, Mazower, 2000; Mesko et al. 2012). Historically, it has been fragmented between big empires and influenced by various cultures, whose impact is evident in language, customs, and food of these nations (Grofelnik, 2014, Mazower, 2000).

As Saric (2004) noted, geography of the Balkans is vague and its scope depends on the geographer's and historian's approach. It is most often described as determined by the mountain ranges of Dinaric Alps, Rhodope Mountains, Sharr Mountains, Pindus Mountains, and the region's eponym, the Balkan Mountains. From this perspective, it encompasses Albania, Bosnia and Herzegovina, Croatia, Kosovo, Macedonia, Montenegro, Serbia, and Slovenia, all of which, bar Albania, formed the Socialist Federal Republic of Yugoslavia from 1945 until the war-ridden breakdown in 1992.

Balkan countries are often analyzed as a homogeneous group, yet certain differences, such as the script and religion, always existed among them and many more emerged during post-socialist transition, or, more recently, joining the European Union (Mazower, 2000; Mesko and Eman, 2015, Mesko et al. 2012 Selih, 2012). These nations were unprepared for a swift transition that resulted in high unemployment, deprivation, and social stress (Flander and Bucar Rucman, 2015, Selih, 2012). In addition, the uncritical appropriation of Western economic, political, and crime and safety models prevented the creation of fully independent countries, built on their own history and ideals (Flander and Bucar Rucman, 2015; Hebenton and Spencer, 1994, Selih, 2012). Subsequently, they created a complicated ethno-national identity, combating the emerging issues of migration and multiculturalism, while still processing their own traumatic and violent history (Volcic, 2013).

Today, almost three decades later, the ambiguities around these countries persist. As member-states of the European Union, Croatia and Slovenia are considered Europe, rather than the Balkans (Saric, 2004), with which they share an entangled socio-cultural legacy (Volcic, 2013). A constant limbo of national ideas and (post-)modernism, as well as the perennial presence of international institutions in this region, might be one of the reasons for their strong expression of regional identity through food. 


\section{Research on Prison Food}

Balanced and healthy meals are important for human growth, development, and the preservation of health, underscoring the need for institutional kitchens (e.g., prison kitchen) to focus on their wards' nutrition (Soher, 2016). Still, research on prison food and prisoners' diet is scarce (e.g., Edwards et al., 2007, Einat and Davidian, 2018, Jones, 2017; Smoyer, 2019, Smoyer and Kjaer Minke, 2015). This is mainly due to limited access to prisons, ethical considerations around this type of research, and prisoners' unwillingness to participate in such studies and/or speak to an outsider (Edwards et al., 2007, Godderis, 2006). Sykes (1958) indicated that prison food might be examined as a subset of prison deprivations; namely, as the deprivation of goods and services, and the deprivation of autonomy. Given its poor taste, food could also be perceived as an additional punitive feature (Sykes, 1958). For those in power, food can become a tool for displaying apathy towards prisoners (Smoyer and Lopes, 2017). It could demonstrate misuse of power by concealing complete or accurate information about food served or by providing misleading information on cooking techniques in food preparation, thus limiting prisoners' ability to make healthy choices (Edwards et al., 2007: Godderis, 2006). For the disempowered, food is a constant reminder of their dependency on the system and their loss of agency (e.g., Edwards et al., 2007, Jones, 2017). Food consumption in prisons tends to be rushed, monitored, and governed by the strict rules regarding when, where, and how much should be eaten (Godderis, 2006, Martinovic, 2012, Smoyer and Lopes, 2017).

Food in prison can encompass more than just meals made and served by the institution. It can refer to a plethora of ways of acquiring food or expressing oneself through food. According to Stajcic (2013), food is a means of communication, which could be used for a higher goal. For example, prisoners can express dissatisfaction with prison environment (e.g., living conditions, medical care, overcrowding) through food strikes that can bring unwanted publicity and initiate change (Maloca, 2017). Food can further be regarded as means to pass time, socialize, earn money and/or benefits while in prison, as well as to acquire skills for future employment (Maloca, 2017, Smoyer and Kjaer Minke, 2015, Spadijer-Dzinic et al., 2009, Zilic, 2017). For a scoping review of international prison food research, see Smoyer (2019), in this thematic issue.

\section{Balkan Prison Systems}

This article focuses on food practices in prison systems in three different countries: Bosnia and Herzegovina (BiH), Croatia, and Serbia. As neighboring countries that used to be a part of one Republic, Yugoslavia, official nutritional guidelines among them are similar, with slight differences in their execution. However, data available for each country vary, as demonstrated throughout this article. One of the main differences between the three prison systems is in the oversight. While Croatian and Serbian systems operate under the auspices of one, respective, national Ministry of Justice, Bosnian system does not. 
Bosnia and Herzegovina (BiH) is comprised of two separate entities, each with their own Ministry: Federation of Bosnia and Herzegovina (FBiH) and the Republic of Srpska (RS) (not to be confused with the Republic of Serbia, a separate country presented in this review). As such, Bosnia publishes two discrete sets of prison statistics.

Table 1: Overview of the Balkan Prison Systems

\begin{tabular}{|c|c|c|c|}
\hline Category & $\begin{array}{l}\text { BOSNIA AND } \\
\text { HERZEGOVINA } \\
\text { (FBIH + RS) }\end{array}$ & CROATIA & SERBIA \\
\hline $\begin{array}{l}\text { Total Country Population } \\
\text { (Source for the country level: worldometers) }\end{array}$ & $\begin{array}{c}3,501,774(2019) \\
(\sim 2,196,233+\sim 1,228,423)\end{array}$ & $\begin{array}{c}4,140,148 \\
(2019)\end{array}$ & $\begin{array}{l}8,733,407 \\
\text { (2019) }\end{array}$ \\
\hline Number of Institutions & $\begin{array}{c}14 \\
(8+6)\end{array}$ & $\begin{array}{c}23 \\
(2016)\end{array}$ & $\begin{array}{c}30 \\
(2017)\end{array}$ \\
\hline $\begin{array}{l}\text { Total Prison Population } \\
\text { (including pre-trial detainees / remand } \\
\text { prisoners) }\end{array}$ & $\begin{array}{c}2,585 \\
(1,722+863) \\
(12 / 2014)(12 / 2017)\end{array}$ & $\begin{array}{l}3,190 \\
(1 / 2018)\end{array}$ & $\begin{array}{l}10,807 \\
(1 / 2018)\end{array}$ \\
\hline $\begin{array}{l}\text { Prison Population Rate } \\
\text { (per } 100,000 \text { of national population) }\end{array}$ & $\begin{array}{l}73(\mathrm{FBiH}) \\
66(2014) \\
(\mathrm{RS})(2017)\end{array}$ & $\begin{array}{c}78 \\
(9 / 2016)\end{array}$ & $\begin{array}{r}154 \\
(2018)\end{array}$ \\
\hline $\begin{array}{l}\text { Occupancy Level } \\
\text { (based on official capacity) }\end{array}$ & $\begin{array}{c}102.1 \%(\mathrm{FBiH}) \\
(1 / 2013) \\
57.8 \%(\mathrm{RS}) \\
(12 / 2017)\end{array}$ & $\begin{array}{l}79.3 \% \\
(1 / 2018)\end{array}$ & $\begin{array}{c}109.2 \% \\
(1 / 2018)\end{array}$ \\
\hline
\end{tabular}

Source: World Prison Brief, 2018

As per Table 1, FBiH is larger in its population size than the RS, has greater prisoner population, and more institutions, yet still operates over its maximum capacity. Serbia demonstrated the highest numbers in all of the indicators examined, while Croatia found itself in the middle (World Prison Brief, 2018). It should be noted that the latest available data differ for each country and entity. As the primary aim of this article is to provide an overview of each separate system, rather than a comparison of all three, the authors opted for the same data source, despite the possibility of some data being dated.

\section{Methodology}

The authors conducted a comprehensive search of national and international online databases for published research on food in Balkan prisons using Croatian and English keywords such as "Prison food", "Food in prisons", "Balkan prisons". The initial search yielded two academic articles examining legal and 
human rights' aspects of prison conditions in Croatia, including issues around food (Babic et al., 2006, Vlahovic and Galovic, 2015); one academic article on deprivations of female prisoners in Serbia, which argued that working on prison farms enabled regainment of autonomy (Spadijer-Dzinic et al., 2009); one Master's thesis on the nutritional value of food in one Croatian prison (Soher. 2016); and a summary of one research poster on a similar topic presented at the 2nd Croatian Congress on Preventative Medicine and Health Promotion (Kendel Jovanovic et al., 2010).

The researchers then e-mailed all four respective Ministries of Justice requesting a sample of their weekly prison menu. The Ministries of Croatia and of the Republic of Srpska provided them directly, whereas the Serbian Ministry instructed the researchers to contact individual institutions, as they did not have this information centrally available. By the time of the article submission, one Serbian prison provided their menu. Since FBiH did not contribute with their menu, when presenting nutritional guidelines, as well as the three specific menus, the term "Bosnian" refers to the Republic of Srpska (RS) entity only.

To supplement the overall scarcity of official and empirical data on this topic, the researchers used online newspaper articles and (ex-)prisoner's blogs. Council of Europe's Report on the Prevention of Torture and Inhuman or Degrading Treatment or Punishment for the three countries, and four entities, is also presented to provide additional information on prison conditions published by a neutral body. These results overlap with government reports, to an extent.

\section{Official Nutritional Guidelines}

Until the early 1990s, the three countries presented in this article used to be one, centrally governed country, Yugoslavia. Consequently, all prisons were run from Belgrade (today's capital of Serbia). Given the strict political regime (Hebenton and Spencer, 1994, Selih, 2012) and a stagnation in the development of criminology in Central and Eastern Europe post-World War II (Hebenton and Spencer, 1994), data on Yugoslavian prison systems are almost non-existent. The majority of public documents focus on communist repression in Croatia towards the end of the WWII and on prison camps in former Yugoslavia, discussing camps' conditions and charges upon individuals disobeying the regime (e.g., Hrvatski Institut za Povijest, Zagreb, 2008, Hrvatski Institut za Povijest, Slavonski Brod, 2006). The one document referring to civilian prisons of that time is the 1951 Yugoslavian Law on the Execution of Criminal Sanctions, Public Safety, and Educational-Correctional Measures.

According to this Law, prisoners were entitled to free meals in accordance with the nutrition table, created by the Minister of the Interior of the Socialist Federal Republic of Yugoslavia (which was not presented within the document) (Federative Council and Council of Nations of the National Assembly of the Socialist Federal Republic of Yugoslavia, 1951). Prisoners were also allowed food packages from the outside once or twice a month, depending on the security level of the institution. One of the institutional sanctions following prisoner misconduct was the revocation of package privileges for up to two months. 
This sanction could not be imposed on pregnant and/or breast-feeding women, unless they repeatedly engaged in misconduct. Pregnant offenders and new mothers were transferred into special prisons, wherein they could stay with their children until the child's first birthday, after which they were transferred back to the institution they were in before childbirth. Children's menu was prescribed by medical professionals and approved by the warden, and food was prepared separately for children and for their mothers.

Prisons further had to secure a way for prisoners to buy food while imprisoned. All prisoners, apart from pregnant women, were obliged to work. Work opportunities were presented as broad categories, but the Law specifically stated that young offenders could work in prisons' agriculture, as well as attend the agricultural school (Federative Council and Council of Nations of the National Assembly of the Socialist Federal Republic of Yugoslavia, 1951).

Some regulations from the Yugoslavian system are visible in today's prison practices as well. Current nutritional guidelines for each prison system are prescribed by their respective Ministries of Justice as part of their Law on the Execution of Criminal Sanctions/Incarceration.

The Republic of Srpska, BiH

Nutritional guidelines prescribed by the Republic of Srpska's Ministry of Justice entitle prisoners to a minimum of three meals a day that must be held up to hygienic and nutritional standards, and take into consideration prisoner's age, culture, religion, health, and work-related demands (Ministry of Justice of Bosnia and Herzegovina, Republic of Srpska, 2018). The guidelines do not clearly specify the way in which working prisoners are given additional food, but the source used would indicate that they receive more food during regular meals, rather than an additional meal (Ministry of Justice of the Republic of Srpska, 2018). Adult prisoners are served a minimum of 3,000cal ( 12,500J) a day and juvenile prisoners $\sim 3,500 \mathrm{cal}(14,500 \mathrm{~J})$ daily (Ministry of Justice of Bosnia and Herzegovina, Republic of Srpska, 2018). Pregnant, breast-feeding, sick, or underage prisoners are entitled to special nutrition prescribed by medical staff (Ministry of Justice of Bosnia and Herzegovina, Republic of Srpska, 2018).

Meals must be served in regular intervals (Ministry of Justice of Bosnia and Herzegovina, Republic of Srpska, 2018) and according to the Ministry of Justice of the Republic of Srpska (2018), the time gap between two meals must not be shorter than four hours, nor longer than eight. Prisoners are given 30 minutes to consume their meal and are not to consume it past the times specified (Ministry of Justice of the Republic of Srpska, 2018). The guidelines further stipulate the requirement of access to drinking water at all times. A dedicated team of professionals appointed by the warden (i.e., a representative of medical staff, a chef, a prisoners' representative, and a person in charge of food supply) creates weekly menus (Ministry of Justice of the Republic of Srpska, 2018). Menus need to be visibly displayed and approachable. A general practitioner or another member of health services in prison is also in charge of monitoring and examining the quality of ingredients and the nutritional value of the meals (Ministry of Justice of Bosnia and Herzegovina, Republic of Srpska, 2018). 
The Republic of Croatia

Croatian prisoners are entitled to a minimum of three meals a day as well, with an additional hot or cold meal, gablec, for working prisoners (Ministry of Justice of the Republic of Croatia, 2010b, Ministry of Justice, Public Administration and Local Self-Government, and Ministry of Health of the Republic of Croatia, 2002). Gablec, or worker's lunch, is quite characteristic for Croatia. Its origins date back to the socialist times, when big-factory workers used to sit together over a free or a very cheap hot meal that would enable them to socialize and give them strength to complete their shift, before going home for their actual lunch (Trkanjec, 2005). Gablec also meant one guaranteed large, hot, healthy meal a day (often stew), made from seasonal ingredients, regardless of the individual's economic status (Trkanjec, 2005). Similarly to Bosnian guidelines, meals served must correspond to hygienic and nutritional standards, and the menus need to account for prisoner's age, culture, religion, health, and the requirements of their work (Ministry of Justice of the Republic of Croatia, 2010b). A minimum of 2,500cal ( 10,500J) a day must be served to adult prisoners, who are not working or are employed in easy jobs (Ministry of Justice, Public Administration and Local Self-Government, and Ministry of Health of the Republic of Croatia, 2002). Those working in jobs of medium difficulty, as well as juveniles, are served a daily minimum of 3,000cal ( 12,500J) (Ministry of Justice of the Republic of Croatia, 2010b Ministry of Justice, Public Administration and Local Self-Government, and Ministry of Health of the Republic of Croatia , 2002), 500 calories less than Bosnian juvenile population. The same as in the latter system, pregnant, breast-feeding, sick, or underage prisoners in Croatian prisons are entitled to special nutrition prescribed by medical staff (Ministry of Justice of the Republic of Croatia, 2010b).

Prisoners must have a constant access to drinking water and their meals need to be served regularly (Ministry of Justice of the Republic of Croatia, 2010b). However, Croatian guidelines do not stipulate a minimum or a maximum time frame between the two meals, possibly due to gablec. Menus are created weekly by a dedicated team appointed by the warden. The team consists of a general practitioner or another representative of medical staff, a chef, a prisoners' representative, and a person in charge of food supply (Ministry of Justice, Public Administration and Local Self-Government, and Ministry of Health of the Republic of Croatia, 2002). According to the same source, the same meal must not be served twice in a row. The quality of food ingredients and the nutritional value of the meals served are monitored and examined by the general practitioner or another member of health services in prison (Ministry of Justice of the Republic of Croatia, 2010b).

Upon admission, Croatian prisoners receive a standard set of dishes that consists of a soup or a stew bowl, a bowl for the main dish, a salad or a fruit bowl, and a 2.5 deciliter cup (Ministry of Justice, Public Administration and Local Self-Government, and Ministry of Health of the Republic of Croatia 2002). Silverware should include a spoon, a fork, a knife, and a teaspoon, all made out of stainless material. In case a part (or parts) of this standard set has been taken away from a prisoner, their food would be pre-cut or served in smaller 
sizes (Ministry of Justice, Public Administration and Local Self-Government, and Ministry of Health of the Republic of Croatia, 2002). However, the Council of Europe (2018a) received several complaints of prisoners not being provided with forks and knives at all, allegedly due to security reasons.

Prisoners on remand have the opportunity to order daily meals either from the prison kitchen or from restaurants unrelated to prisons (Ministry of Justice of the Republic of Croatia, 2010a). If they decide to do so, they need to submit a written request to prison administration at least 48 hours in advance. Prison warden will grant approval upon their discretion. Such meals are paid for from prisoner's personal account. According to the Ministry of Justice of the Republic of Croatia (2010a), if a special meal is requested from the prison kitchen, its price is set as the price of ingredients increased by the cost of energy and chef's time. Convicted prisoners, if granted special privileges, can prepare their own meals and beverages within prison (Ministry of Justice of the Republic of Croatia, 2010b, Vlahovic and Galovic, 2015). Privileges can be earned through prisoners' monthly evaluations, conducted by the treatment team (Vlahovic and Galovic, 2015).

The Republic of Serbia

Similarly to the other two prison systems, Serbian guidelines also stipulate that meals must be served at least three times a day and drinking water must be accessible at all times (Ministry of Justice of the Republic of Serbia, 2014). However, these guidelines are somewhat narrower, stating only that meals must be adequate to retain prisoner's health and strength, and in accordance with their religious beliefs. Those working in hard labor, sick prisoners, and pregnant and/or breast-feeding women are eligible for nutrition prescribed by medical staff. The daily minimum of calories served is 3,000 $(\sim 12,500 \mathrm{~J})$ for adult prisoners and the guidelines do not reflect on this matter regarding juvenile offenders (Ministry of Justice of the Republic of Serbia, 2014).

Overall, prisoners in all three prison systems are entitled to three meals a day and drinking water must be available and accessible at all times. Furthermore, the warden or another person entitled by the warden (e.g., medical personnel) will taste the food before each serving and write their remarks in a special journal, Journal of Food Monitoring, in all three systems (Ministry of Justice of Bosnia and Herzegovina, Republic of Srpska, 2018; Ministry of Justice, Public Administration and Local Self-Government, and Ministry of Health of the Republic of Croatia, 2002 Ministry of Justice of the Republic of Serbia, 2014). Croatian guidelines further stipulate that if food quality is substandard, serving will be forbidden and prisoners will receive an alternative meal (Ministry of Justice, Public Administration and Local Self-Government, and Ministry of Health of the Republic of Croatia, 2002). Although food ingredients and meals served should adhere to nutritional guidelines and the recommended calorie intake, high levels of calories do not necessarily indicate nutritious and healthy food, which tends to be supported by quality analyses of prison food (see Jacobs and Mullany, 2015; Kendel Jovanovic et al., 2010, Soher, 2016. 


\section{Sample Menus}

As was already discussed, the authors received a sample of weekly menus (in their native language) from one institution in the Republic of Srpska and one in Croatia, courtesy of their respective Ministries of Justice, as well as from one institution in Serbia, courtesy of that institution (specific information on each institution is known to the authors). All menus were used in their institutions in August/September 2018. The researchers translated them into English and presented them as they were. As a result, the information provided is not unified and one menu can be more detailed than another. While Croatian and Serbian menus entailed the caloric value of the meals served, the Bosnian one did not. However, the Serbian menu used Joules, while the Croatian one used calories. To allow for easier comparison, the researchers converted all values into calories. Despite Joules being in accordance with the International System of Units for energy, popularity and a wider public use of calories prompted the researchers to opt for the latter. The following three tables present weekly menus for adult male prisoners with no specific dietary requirements.

\section{The Republic of Srpska, BiH}

Bosnian menu looks quite repetitive, with identical breakfasts and lunches on Wednesdays and Saturdays, and dinners on Mondays and Thursdays. Tea is served daily, for breakfasts. Prisoners sometimes have soup for lunch and a dessert is served once a week.

Table 2: Weekly menu in RS (BiH)

\begin{tabular}{|l|l|l|l|l|l|l|l|}
\hline Breakfast & Monday & Tuesday & Wednesday & Thursday & Friday & Saturday & Sunday \\
\hline $\begin{array}{l}\text { margarine, } \\
\text { tea }\end{array}$ & $\begin{array}{l}\text { Boiled hot } \\
\text { dogs, } \\
\text { boiled } \\
\text { eggs, } \\
\text { mustard, } \\
\text { tea }\end{array}$ & $\begin{array}{l}\text { Fried eggs, } \\
\text { cheese, tea }\end{array}$ & $\begin{array}{l}\text { Sardines, } \\
\text { onion, tea }\end{array}$ & $\begin{array}{l}\text { Sausage, } \\
\text { mustard, } \\
\text { tea }\end{array}$ & $\begin{array}{l}\text { Fried eggs, } \\
\text { cheese, tea }\end{array}$ & $\begin{array}{l}\text { Margarine, } \\
\text { jam, tea }\end{array}$ \\
\hline Lunch & $\begin{array}{l}\text { Oven- } \\
\text { baked } \\
\text { chicken, } \\
\text { beans, rice }\end{array}$ & $\begin{array}{l}\text { Soup, } \\
\text { mousakka, } \\
\text { salad }\end{array}$ & $\begin{array}{l}\text { Beans stew } \\
\text { with bacon, } \\
\text { salad }\end{array}$ & $\begin{array}{l}\text { Goulash, } \\
\text { macaroni, } \\
\text { salad }\end{array}$ & $\begin{array}{l}\text { Fried fish, } \\
\text { potato, } \\
\text { salad, } \\
\text { strudel }\end{array}$ & $\begin{array}{l}\text { Beans stew } \\
\text { with } \\
\text { bacon, } \\
\text { salad }\end{array}$ & $\begin{array}{l}\text { Soup, } \\
\text { mashed } \\
\text { potatoes, } \\
\text { meat balls } \\
\text { in tomato } \\
\text { sauce, } \\
\text { salad }\end{array}$ \\
\hline Dinner & Fried eggs & $\begin{array}{l}\text { Macaroni } \\
\text { with cheese }\end{array}$ & $\begin{array}{l}\text { Polenta, } \\
\text { yoghurt }\end{array}$ & Fried eggs & $\begin{array}{l}\text { Spaghetti } \\
\text { bolognese }\end{array}$ & $\begin{array}{l}\text { French } \\
\text { toast, } \\
\text { cheese, } \\
\text { yoghurt }\end{array}$ & Páte, fruit \\
\hline
\end{tabular}

Apart from the availability of a daily religious menu, prisons in Bosnia prepare special feasts for big religious holidays, such as the Catholic or Orthodox 
Christmas and Easter, when meals are accompanied by cakes (Zilic, 2017). For example, for Bayram (for prisoners of Islamic faith) meals are prepared in accordance with Muslim customs and served with traditional sweets, such as baklava, sweet layered pastry filled with nuts. The menu presented contained no information regarding the daily amount of calories served or the slices of bread available to prisoners.

The Republic of Croatia

Unlike Bosnian prisons, Croatian ones serve a variety of drinks for breakfasts (i.e., tea, cocoa, milk, or coffee) and a different meal every day. Apart from the three main meals, Croatian prisons offer gablec for prisoners engaged in work. Yet, according to the menu, gablec is a cold, bread-heavy meal, probably due to practicalities and constraints of cooking an additional meal for this population.

Table 3: Weekly menu in Croatia

\begin{tabular}{|c|c|c|c|c|c|c|c|}
\hline & Monday & Tuesday & Wednesday & Thursday & Friday & Saturday & Sunday \\
\hline Breakfast & $\begin{array}{l}\text { Hamburger } \\
\text { bacon, } \\
\text { cheese, tea }\end{array}$ & $\begin{array}{l}\text { Pâté, } \\
\text { cacao }\end{array}$ & Nutella, tea & $\begin{array}{l}\text { Cheese } \\
\text { spread, } \\
\text { salami, tea }\end{array}$ & $\begin{array}{l}\text { Honcy, } \\
\text { butter, white } \\
\text { coffee }\end{array}$ & Cereals, milk & $\begin{array}{l}\text { Sausages, } \\
\text { mustard, tea }\end{array}$ \\
\hline Calories & 831 & 810 & 852 & 865 & 825 & 869 & 748 \\
\hline $\begin{array}{l}\text { Gablec } \\
\text { (workers' } \\
\text { lunch) }\end{array}$ & $\begin{array}{l}\text { Boiled egg, } \\
\text { salami, } \\
\text { yoghurt }\end{array}$ & $\begin{array}{l}\text { Salami, } \\
\text { hard } \\
\text { cheese, } \\
\text { yoghurt }\end{array}$ & $\begin{array}{l}\text { Hamburger } \\
\text { bacon, cheese, } \\
\text { onion, yoghurt }\end{array}$ & $\begin{array}{l}\text { Cold cuts, } \\
\text { onion, } \\
\text { yoghurt }\end{array}$ & $\begin{array}{l}\text { Sardines in a } \\
\text { can, yoghurt }\end{array}$ & $\begin{array}{l}\text { Cheese } \\
\text { spread, milk }\end{array}$ & Pâté, tea \\
\hline Calories & 572 & 704 & 652 & 672 & 682 & 509 & 793 \\
\hline Lunch & $\begin{array}{l}\text { Beans stew, } \\
\text { sausage, } \\
\text { salad }\end{array}$ & $\begin{array}{l}\text { Goulash, } \\
\text { pasta, } \\
\text { salad, } \\
\text { pudding }\end{array}$ & $\begin{array}{l}\text { Pork cutlet, rice } \\
\text { with peas, salad }\end{array}$ & $\begin{array}{l}\text { Mixed stew, } \\
\text { pork } \\
\text { shoulder, } \\
\text { salad }\end{array}$ & $\begin{array}{l}\text { Fried fish, } \\
\text { vegetables, } \\
\text { potato, } \\
\text { salad, fruit }\end{array}$ & $\begin{array}{l}\text { Soup, roasted } \\
\text { chicken, } \\
\text { mlinci (pasta- } \\
\text { tatters), salad }\end{array}$ & $\begin{array}{l}\text { Soup, veal steak, } \\
\text { mashed } \\
\text { potatoes, } \\
\text { satarash } \\
\text { (ratatouille), } \\
\text { salad, cake }\end{array}$ \\
\hline Calories & 1,331 & 1,221 & 1,252 & 1,265 & 1,206 & 1,290 & 1,456 \\
\hline Dinner & $\begin{array}{l}\text { French } \\
\text { toast, } \\
\text { hot-dogs }\end{array}$ & $\begin{array}{l}\text { Đuved } \\
\text { with rice, } \\
\text { sausage }\end{array}$ & $\begin{array}{l}\text { Fried luncheon, } \\
\text { egeplant with } \\
\text { tomato and } \\
\text { cheese }\end{array}$ & $\begin{array}{l}\text { Spaghetti } \\
\text { Milanese, } \\
\text { grated } \\
\text { cheese }\end{array}$ & $\begin{array}{l}\text { Pasta with } \\
\text { cheese, } \\
\text { yoghurt }\end{array}$ & $\begin{array}{l}\text { Grits, cacao } \\
\text { powder }\end{array}$ & $\begin{array}{l}\text { Tuna can, fruit, } \\
\text { yoghurt (dried } \\
\text { dimner) }\end{array}$ \\
\hline Calories & 984 & 995 & 961 & 944 & 990 & 992 & 679 \\
\hline $\begin{array}{l}\text { Total Cal } \\
\text { (w' bread) }\end{array}$ & 4,968 & 4,980 & 4,967 & 4,996 & 4,953 & 4,910 & 4,926 \\
\hline
\end{tabular}

Lunch in Croatian prisons occasionally includes soup and a dessert is served three times a week, twice for lunch and once as a dinner. As a largely Catholic country, Friday Fast is evident in the prison menu. Traditionally, one was to abstain from eating animal meet on Fridays and have fish instead. The daily amount of calories served is regularly over the 3,000 calories minimum and with gablec it can reach almost 5,000. Prisoners receive over 1,200 calories from bread (over ten slices) daily. However, data only represents the amount of calories served, not the amount of calories consumed by the individuals. 
The Republic of Serbia

According to the Table 4, Serbian prisoners are served an additional drink for breakfast only on weekends (guidelines already stipulate the necessity for water to be available and accessible at all times). Their lunch does not entail soup, but stews are served frequently. Lunches are also quite heavy on vegetables. Serbian prisons do not offer a dessert, yet they serve a sweet dinner (rice pudding and grits) twice a week. Similarly to Bosnia, Friday Fast is not evident in Serbian menu, although it is a custom in Eastern Orthodoxy too.

Serbian menu seems to be very exact, in that it stipulates the ideal serving size of each item (in grams). Every meal is served with a total of $250 \mathrm{~g}$ of bread (about four slices), apart from one dinner a week, indicated with an *. This amounts to a moderate daily range of 3,250 to $3,850 \mathrm{cal}$ served.

Table 4: Weekly menu in Serbia

( $250 \mathrm{~g}$ of bread is served with every single meal, apart from the one dinner marked with *)

\begin{tabular}{|c|c|c|c|c|c|c|c|}
\hline & Monday & Tuesday & Wednesday & Thursday & Friday & Saturday & Sunday \\
\hline Breakfast & $\begin{array}{l}\text { Sardine } \\
(125 \mathrm{~g})\end{array}$ & $\begin{array}{l}\text { Salami }(50 \mathrm{~g}) \text {, } \\
1 \text { egg }\end{array}$ & $\begin{array}{l}\text { Sardine } \\
(125 \mathrm{~g})\end{array}$ & $\begin{array}{l}\text { Brats } \\
(100 \mathrm{~g}) \text {, } \\
\text { mustard } \\
(20 \mathrm{~g})\end{array}$ & $\begin{array}{l}\text { Cold cut } \\
(100 \mathrm{~g})\end{array}$ & $\begin{array}{l}\text { Tea }(2 \mathrm{del}) \text {, } \\
\text { jam }(50 \mathrm{~g}) \text {, } \\
\text { butter }(50 \mathrm{~g})\end{array}$ & $\begin{array}{l}\text { Yoghurt } \\
(2 \mathrm{dcl}) \text {, } \\
\text { sausage } \\
(100 \mathrm{~g})\end{array}$ \\
\hline Cal (w/ bread) & 1,009 & 1,009 & 1,009 & 1,015 & 1,009 & 1,170 & 961 \\
\hline Lunch & $\begin{array}{l}\text { Beans } \\
(400 \mathrm{~g}) \text { with } \\
\text { smoked } \\
\text { meat }(90 \mathrm{~g}) \text {, } \\
\text { tomato } \\
(150 \mathrm{~g})\end{array}$ & $\begin{array}{l}\text { Mashed } \\
\text { potatoes } \\
(300 \mathrm{~g}) \text {, } \\
\text { veal goulash } \\
(200 \mathrm{~g}), \\
\text { salad }(400 \mathrm{~g}) \text {, } \\
\text { grilled peppers } \\
(150 \mathrm{~g})\end{array}$ & $\begin{array}{l}\text { Macaroni } \\
(300 \mathrm{~g}), \\
\text { chicken } \\
\text { paprikash } \\
(200 \mathrm{~g}), \\
\text { pickle }(150 \mathrm{~g}) \text {, } \\
\text { peach }\end{array}$ & $\begin{array}{l}\text { Beans } \\
(400 \mathrm{~g}) \text { with } \\
\text { smoked } \\
\text { meat }(90 \mathrm{~g}) \text {, } \\
\text { tomato } \\
(150 \mathrm{~g})\end{array}$ & $\begin{array}{l}\text { Baked rice } \\
\text { with } \\
\text { vegetables } \\
(400 \mathrm{~g}) \text {, } \\
\text { fried hake } \\
(150 \mathrm{~g}) \text {, } \\
\text { onions }\end{array}$ & $\begin{array}{l}\text { Vegetable } \\
\text { paprikash } \\
(400 \mathrm{~g}), \\
\text { grilled } \\
\text { chicken } \\
(100 \mathrm{~g})\end{array}$ & $\begin{array}{l}\text { Peas } \\
(400 \mathrm{~g}) \\
\text { with } \\
\text { chicken } \\
(100 \mathrm{~g}) \text {, } \\
\text { red beets } \\
(150 \mathrm{~g})\end{array}$ \\
\hline Cal (w/ breed) & 1,556 & 1,402 & 1,449 & 1,556 & 1.254 & 1,728 & 1,384 \\
\hline Dinner & $\begin{array}{l}\text { Rice } \\
\text { pudding } \\
(400 \mathrm{~g})\end{array}$ & $\begin{array}{l}\text { Pilaf }(400 \mathrm{~g}) \\
\text { with chicken } \\
(50 \mathrm{~g})\end{array}$ & $\begin{array}{l}\text { French toast } \\
(250 \mathrm{~g}), \\
\text { cheese }(50 \mathrm{~g})^{8}\end{array}$ & $\begin{array}{l}\text { Baked } \\
\text { macaroni } \\
(300 \mathrm{~g}) \text { with } \\
\text { ground } \\
\text { meat }(90 \mathrm{~g})\end{array}$ & $\begin{array}{l}\text { Green beans } \\
(400 \mathrm{~g}) \text { with } \\
\text { chicken }(50 \mathrm{~g})\end{array}$ & Grits $(400 \mathrm{~g})$ & $\begin{array}{l}\text { Sardine } \\
(125 \mathrm{~g})\end{array}$ \\
\hline Cal (w/ bread) & 1,002 & 1,001 & 879 & 1,280 & 986 & 879 & 1,009 \\
\hline $\begin{array}{l}\text { Total Cal } \\
\text { (with bread) }\end{array}$ & 3,567 & 3,412 & 3,337 & 3,852 & 3,248 & 3,777 & 3,354 \\
\hline
\end{tabular}

To conclude, all three menus demonstrated serving some ethnic, regional meals (e.g., goulash, beans stew, mousakka, paprikash, and grits, even sardines in a can). As discussed earlier, Balkan food is intertwined with German, Austrian, Hungarian, Italian, and Turkish influences, but modified to fit each culture. Menus further display some other cultural specificities, such as gablec, soup, and/or a side of salad for nearly every lunch. This could indicate the expression of a (lost) Yugoslavian identity, despite the independence and a degree of Westernization of each country. 


\section{Prison Conditions}

When examining nutritional guidelines, official menus, and newspaper articles on prison food, there are certain disparities around food and food standards, especially among prisons within the same system (Jakelic, 2003). Food is often considered bland, monotonous (Jakelic, 2003, Nesic, 2014b), monochromatic, and of substandard quality (e.g., under-cooked vegetables or soured canned vegetables) (Nesic, 2014b). This might be due to subjectivity and personal experiences of the overall prison environment (see Gaes, 1994 , Johnson and Toch, 2000, Tewksbury, 2006, Toch, 1990). Individual's understanding of food in different prisons could be driven by that institution's security level, prisoner-staff relationships, sentence length, overcrowdedness, and other factors that might cause spurious relationship between one's perception of their own well-being and the environment. However, this could also indicate a legitimate, objective concern for prison authorities, as it could raise a human rights issue. Selih (2012) reported that prison conditions in Central and Eastern European countries, apart from Slovenia, have always been poor with daily violations of human rights and staff uninterested in prisoners' welfare. The report by the Council of Europe (2016b) mainly supports complaints in Serbian prisons around unhygienic and substandard conditions of food preparation areas, food distribution in metal buckets unable to retain heat, and monotonous food that lacks fruit and vegetables. The latter, however, contradicts the menu presented.

Perceptions of food, as well as prisoners' overall treatment in each country, could also reflect the national ethos around crime and punishment. Mesko and Eman (2015) reported on their cross-national comparison of perceptions of police legitimacy and effectiveness among undergraduate law students in seven Central and Eastern European countries. They found that Serbian students ranked the perceived police legitimacy the lowest, yet held the highest perceptions of the effectiveness of procedural justice, as well as of moral credibility of the legal system. On the contrary, Croatian students displayed the lowest trust in moral credibility of the system, but the highest willingness to cooperate with the police. Bosnian students ranked the perceived effectiveness of the police the lowest (Mesko and Eman, 2015). These results could indicate societal perceptions of prisoners and their trust in the criminal justice system as a whole. According to Mesko and Eman (2015), some of their results are in accordance with the unification of crime control practices and democratization of the justice system given the individual EU memberships.

When looking at the Council of Europe's reports on the Prevention of Torture in prison in these three countries, Serbia received most allegations (supported by medical evidence) of physical ill-treatment, even electrical shocks, of detainees during questioning and imprisonment (Council of Europe, 2018b, 2016b). The cells were dilapidated and overcrowded with inadequate ventilation, insufficient light, and poor hygienic conditions, often with no mattresses or bedding (Council of Europe, 2016b, 2018b). Detainees, as well as prisoners, were locked up for over 22 hours a day, with little or no access to education and/or purposeful activities, including recreation. Poor conditions, joint with

under-staffing, led to high levels of interpersonal violence and intimidation 
in Serbian prisons (Council of Europe, 2016b), which could manifest in their overall poorer experiences of prison food. The report requested action to ensure detainees received water and food at appropriate times (Council of Europe, 2018b) and that the quality and quantity of food given to prisoners is of adequate temperature, in accordance with the hygiene standards and in compliance with nutritional guidelines (Council of Europe, 2016b).

The report on Croatia contained some allegations of physical ill-treatment, but those were an exception, rather than the norm (Council of Europe, 2018a). There was an improvement regarding over-crowding and overall prison conditions, yet the report raised concerns about the lack of purposeful activities, short amount of hours outside of the cells, and inter-prisoner violence.

Finally, the Council of Europe found almost no allegations of physical ill-treatment of prisoners in the Republic of Srpska, with most prisoners stating they felt safe in custody (Council of Europe, 2016a). This is in line with the newspaper article on one of the prisons in the RS (M.D. 2015). However, it should be noted that the report examining $\mathrm{FBiH}$ entity of Bosnia produced more negative results, which corresponds to the statistical data presented earlier.

Although the Council of Europe's reports paint a rather negative picture of certain aspects of imprisonment in each of the countries examined, the disparities (and their extent) between those reports and data from the official, government reports, could be due to different methods of evaluations conducted and further differences in indicators examined.

\section{Prison Commissary, Prison Farms, and Food Packages}

Apart from prisons' legal requirements to serve regular meals, prisoners often have other ways of acquiring food and food products. Although most of those pathways are allowed, even enabled by the institution, certain products could be (mis)used for illegal trade, as a currency, or to reiterate prison hierarchy. Research on prison sociology in the Balkans is scant, yet the main tenets of prisonization and prisoner culture seem to transcend geographic boundaries (Akers et al., 1977). One of the central aspects of this culture is power (see Clemmer, 1940, Crewe, 2009: McCleery, 1960, Tewksbury, 2006). Power can come from possessions, possessions bring status, and status ensures survival, or at least an improvement of the quality of life in such a deprived environment (Crewe, 2009 Spadijer-Dzinic et al. 2009). Prisoners in the Balkans use food, cigarettes, and coffee to (partly) re-gain their autonomy, reconstruct their identity, and secure their place in prison hierarchy through obtainable goods and services (Martinovic, 2012, Nesic, 2016, Spadijer-Dzinic et al., 2009).

\section{Prison Commissary}

Prison stores can offer a variety of food and hygienic products, cigarettes, even board games (Soher, 2016; Nesic, 2014c). Prisoners can buy candy, milk and dairy products, processed meat, and fruit (Soher, 2016), but according to M.D. (2015), Bosnian prisoners most often buy chocolate. Some Bosnian 
prisons have a coffee shop too, wherein prisoners can have coffee during specific times of day (Ministry of Justice of the Republic of Srpska, 2018). Croatian prisoners can order special food items, such as gluten-free or lactose-free ones (Soher, 2016). If a prison does not have a store on site, it must acquire the items needed through different means (Ministry of Justice of the Republic of Croatia, 2018; Ministry of Justice of the Republic of Srpska| 2018).

Prices, opening hours, and shopping procedures vary between, as well as within, prison systems. According to Nesic (2014c), Serbian commissary is staffed by a female cashier and two prisoners, whose job is to bring the items listed on a prisoner's shopping list. Each cell block has one assigned shopping day a week, but not the specific time. Prison officer could come at any point between $8 \mathrm{am}$ and 4 or $5 \mathrm{pm}$ to take prisoners to the store, which leads to anxiety and a constant state of preparedness among prisoners (Nesic, 2014c), not to miss their weekly shopping trip. Going to the store is described as something out of the ordinary that brings pride and content, feelings of having accomplished something important and pleasant (Nesic, 2014c). According to Nesic (2014c), it is difficult to describe to an outsider the happiness that a 10-minute journey to prison commissary provides in a grim, monotonous treadmill of a prison life. Vidic (2009) argued that prisoners in some Serbian prisons are not allowed to go to the store, but create a weekly shopping list instead and have the items delivered to their cells. The downside of such business is the unfamiliarity with the prices. Money is taken from prisoners' accounts, without a justification of costs or a receipt for their purchase (Vidic, 2009). On the contrary, the Ministry of Justice of the Republic of Srpska (2018) demands price-lists in Bosnian (RS) prisons to be openly displayed and prices to be equal to the wholesale ones, increased only by tax, to ensure no profit would be made from this trade.

According to Martinovic (2012), prisons set their own prices, tying the suppliers to prison management; when the management changes, commissary suppliers change as well (Vidic, 2009). Apparently, prison prices can therefore be up to 20-30\% higher than in the supermarkets outside of Serbian prisons (Nesic, 2014c) or up to $50 \%$ more in Croatian prisons (Jakelic, 2003). The only item with a standardized price are cigarettes (Nesic, 2014c). This might reflect these countries' corruption level; a remnant from the socialist system precipitated by the breakdown (Flander and Bucar Rucman, 2015 Hebenton and Spencer, 1994, Selih, 2012). Examining the Transparency International Corruption Perception Index (CPI), each country displayed a different corruption trend from 2003 (the first year with data available for all three countries) until 2018 (the latest data published). Croatia's index remained basically unchanged, with slight oscillations, from the $59^{\text {th }}$ place in 2003 to the $60^{\text {th }}$ in 2018. Serbia dropped from the $106^{\text {th }}$ place in 2003 to the $87^{\text {th }}$ in 2018, and the CPI rank increased in Bosnia and Herzegovina from the $70^{\text {th }}$ place in 2003 to the $89^{\text {th }}$ in 2018 (Transparency International, 2018). These rankings are quite high, when compared to the Scandinavian or Western-European countries, which might further dictate the overall prison conditions and the negotiation of power. 
Prison Recipes

Some prisoners do not have money to order meals from the outside or buy luxurious food items from the commissary, so they come up with ingenious recipes for prison meals (Nesic, 2014d). Those recipes travel fast from cell to cell, from block to block, not only in prisons in this region. According to Nesic (2014d) and Smoyer and Kjaer Minke (2015), although unimaginable to people on the outside, prisoner-made meals are quite tasty, especially when compared to prison-served food. Making one's own food from the ingredients available can relay a sense of camaraderie, normalcy, and satisfaction amid a gloomy routine. International research further noted that meal preparation enables prisoners to regain autonomy and partial control over their bodies and nutrition (Johnson and Toch, 2000, Sykes, 1958, Ugelvik, 2011). Some of the most common meals prisoners in the Balkans make include grilled sausages, where grills are made using pâté cans filled with margarine and a table cloth in the middle to ensure slow burning of the fat; salads, which contain everything but vegetables; meals from the Italian cuisine with everything but meat; or sandwiches made from anything available. A famous dessert is prison cake, served on a large piece of cardboard or a (temporarily borrowed) cupboard door (Nesic, 2014d).

\section{Prison Farms}

Given the tight budget prisons operate on, some allow prisoners to work with food, supplementing their nutrition with fresh fruits and vegetables, milk, meat, and eggs (Council of Europe, 2016b: The Government of the Republic of Croatia, 2017). These practices are seen in other countries as well (Smoyer and Kjaer Minke, 2015: Ugelvik, 2011). Prisoners can be employed in the kitchen, the dining hall, on prison farms and in prison gardens breeding pigs and cattle (Hina, 2017, Maloca, 2017, Spasenic, 2016). They can also work towards a qualification in baking or simple meals' preparation (e.g., pizza or burek, baked filled pastry made of thin, flaky dough), potentially contributing to their post-release employment success (Zilic, 2017). Despite dated tools and machinery, in addition to the limited production capacity (Spasenic, 2016), many prisoners are willing to work, but the positions available are limited (Maloca, 2017, Spadijer-Dzinic et al., 2009, Spasenic, 2016).

In Croatian prisons, farm animals typically include sheep, goats, cows, and rabbits (Jakelic, 2003, The Government of the Republic of Croatia, 2017). Prisoners can grow plants or animal feed, such as potatoes and/or oats. The majority of production is intended for prison's own purposes (Hina, 2003) or sent to other Croatian prisons, yet some can be sold at the open market too (HRT Vijesti, 2013). According to Spasenic (2016) and Klix (2016), six prisons in BiH have production units too, divided into agricultural units, farms, workshops, restaurants, kitchenettes, bakeries, laundry rooms, and others.

Prisoners of both genders can be employed in these sectors and Spadijer-Dzinic et al. (2009) found that women prisoners aimed for this line of work to regain autonomy. It enabled them to enjoy fresh air, chat with other female prisoners, and meet male prisoners from other prisons, working on 
a farm too. Farm jobs equipped prisoners with practical skills (e.g., plowing land and planting seeds), while providing a moral lesson of putting effort into something and enjoying the outcomes of one's work (Spadijer-Dzinic et al., 2009 Zilic, 2017). Additionally, work was used to pass time and earn money, but it also elicited feelings of accomplishment and enjoyment, and was a step towards a social reintroduction of prisoners as effective citizens (Maloca, 2017. Spadijer-Dzinic et al. 2009). Finally, prisons sometimes motivated those who constantly proved themselves as good workers through weekend furloughs or monetary incentives (Zilic, 2017).

\section{Food Packages}

Apart from growing food or buying it from commissary, prisoners in Serbia and Bosnia can receive food packages from outside or have food brought in during visitations (Ahbabovic, 2017; Vidic, 2009). Croatian prisoners can accept packages with allowed items, but the Ministry of Justice of the Republic of Croatia (2010b) does not specify what those items include. In all three countries the frequency of receiving packages, as well as their size, are regulated by their respective Ministry. In $\mathrm{BiH}$, for example, the overall weight of food packages must not supersede eight kilograms (Ahbabovic, 2017, Klix, 2016). Packages are subject to restriction, search, and seizure. Food sent in needs to be packed in plastic, see-through bags, and will be scanned upon admission (Ahbabovic, 2017, Vidic, 2009). While Serbia bans some food items that can be turned into weapons (e.g., chicken) (Vidic, 2009), in $\mathrm{BiH}$ food needs to be boneless and cut into small pieces (Ahbabovic, 2017). According to Nesic (2014c)'s prison blog, items such as juice, spreads, cookies with cream, or tea bags are not to be sent in packages, but can be bought in prison stores.

Receiving packages from the outside can evoke prisoner solidarity through sharing or trading of items. Whether it is a friendly relationship or just an interest union, it can make one's life easier (Spadijer-Dzinic et al., 2009). Yet, packages can also mirror a problem from the civilian life - differentiation in wealth, causing arguments, theft, and exploitation of the "have-nots" (Spadijer-Dzinic et al., 2009). Depending on their family's financial situation, a package can become a status symbol influencing one's reputation throughout imprisonment (see also Smoyer, 2019). It can perpetuate creation and maintenance of social relationships, reiterating prison hierarchy (Spadijer-Dzinic et al. 2009, Vidic, 2009). Some prisoners, therefore, intentionally order highly valued goods, such as coffee, cosmetic products, or cigarettes, to boost their status and gain respect (Nesic, 2016, Spadijer-Dzinic et al., 2009).

\section{The Role of Coffee and Cigarettes}

Through globalization and the media, coffee became a synonym for relaxation and break, partially losing its original association with nerve stimulation and alertness (Barthes, 2012). It is a pillar-stone of the Balkan culture, a ritual that can last for hours. In her article on mixing of youth from 
three ethnicities in $\mathrm{BiH}$, Hromadzic (2011) emphasized the, almost glue-like, role of coffee and cigarettes in bridging ethnic divisions. Smoking and drinking coffee created an inter-ethnic public arena where youth could socialize. In Serbian female prisons, being invited for a coffee symbolizes acceptance (belonging) into a social group or an invitation for a sexual encounter (Spadijer-Dzinic et al. 2009). Coffee is also used as currency, whereby more experienced prisoners share their wisdom with newcomers, provided they make them coffee. It is further used to pay other prisoners for services, such as doing laundry or ironing. Similarly to food packages, possessing coffee can cause jealousy, envy, and conflict among prisoners, but also enable social cohesion - if a prisoner is extremely poor and cannot afford to buy coffee or receive a package, they will still be invited for a coffee. Yet, in such cases, that prisoner tends to find a way to acquire some goods and give their share to the group (Spadijer-Dzinic et al., 2009).

Cigarettes are yet another item symbolizing prestige in prison settings. Prisoners often order foreign cigarettes in food packages to gain respect (Spadijer-Dzinic et al. 2009). As well as coffee, cigarettes too are used as currency, often for card games played in prison. The highest bets are placed for poker (Nesic, 2014a). As per Nesic (2014a), they can range from as little as five cigarettes up to full cartons, sometimes leaving a prisoner heavily indebted. Although possession of goods can create supportive units, alleviate deprivations of prison life, and bring some autonomy back to prisoners, it can also lead to further marginalization of those with less buying power and reiterate prison hierarchy.

\section{Conclusion}

This article presented an overview of food practices in three independent countries in the Balkans: Bosnia and Herzegovina (the Republic of Srpska entity), the Republic of Croatia, and the Republic of Serbia. As an EU member state, Croatia had to align its crime control policies to those of the Union, whereas Bosnia and Serbia remained excluded (Mesko and Eman, 2015). This might have led to certain differences in treatment of prisoners, yet research on the perceptions of fear of crime in six capitals of former Yugoslavia found that variables used in this type of research in Western Europe can be applied to the Balkan context too (Mesko et al., 2012). International research on criminology and prisoner culture further indicated that certain ideas transcend geographical boundaries (Akers et al., 1977, Hebenton and Spencer, 1994). Although the three countries examined in this review were once a single Republic, each one went their separate ways post-transition. Still, the sample menus presented reflect many tenets of the Balkan culture strongly interwoven in prison food practices (i.e., gablec, soup, a side of salad, regional meals).

This article then highlighted further opportunities for prisoners to regain autonomy through prison stores, farm jobs, and food packages received from the outside, some of which is evident in Western countries as well (Smoyer and Kjaer Minke, 2015; Ugelvik, 2011). It underscored the role of coffee and cigarettes in socialization, re-creation of the outside life, and affirmation of 
support and cohesion among prisoners. Alternative pathways of acquiring and consuming food in prison can provide normalcy and relief within the context of multiple deprivations. On the other hand, they can be misused to reiterate prison hierarchy through differentiation of wealth, which can lead to jealousy, fights, and further segregation of individuals.

Despite political, cultural, and historical peculiarities of the Balkans, this article demonstrated that general findings from an international prison research could be applied to this geographical area too. However, given the irrefutable importance of food for one's mental and physical health, and the additional layers of meaning food can embody in prison settings, beyond sheer survival, the researchers would encourage further empirical work in this geo-historical region to elucidate the intersectionality of culture, identity, food, and imprisonment.

\section{Notes}

Apart from the regular menu for adult prisoners presented in this review, the authors also received menus reflecting special dietary requirements as follows:

a) Bosnia (RS): menu for juvenile offenders

b) Croatia: low-fat (diet) menu, menu for prisoners suffering from diabetes, menu for prisoners suffering from gout, religious menu (unspecified which religion), and vegetarian menu (around 4,900cal daily each)

c) Serbia: menu for prisoners suffering from diabetes (highest average daily caloric value at $18,400 \mathrm{~J} ; \sim 4,400 \mathrm{cal})$, menu for prisoners with ulcer, and religious menu (Islam) (each around 14,400J; 3,400cal daily)

\section{Declaration of Conflicting Interests}

The authors declared no potential conflicts of interest with respect to research, authorship, and/or publication of this article.

\section{Funding}

This research did not receive any specific grants from funding agencies in public, commercial, or not-for-profit sectors.

\section{References}

Ahbabovic, H. (2017). Uslovi u BH zatvorima: Ne smije se unositi sarma, zatvorenici imaju karticu sa sedam brojeva, u Zenici postoji uredaj koji ometa rad mobitela. http://www.source.ba/clanak/Haris/447882/Uslovi-ubh-zatvorima--Ne-smije-se-unositi-sarma-zatvorenici-imajukarticu-sa-sedam-brojeva-u-Zenici-postoji-uredjaj-koji-ometarad-mobitela. Accessed: 12 February 2019. 
Akers, R., Hayner, N., and Gruninger, W. (1977). Prisonization in Five Countries: Type of Prison and Inmate Characteristics. Criminology, 14, 527-554. doi:10.1111/j.1745-9125.1977.tb00042.x.

Babic, V., Josipovic, M., and Tomasevic, G. (2006). Hrvatski Zatvorski Sustav i Zastita Ljudskih Prava Zatvorenika. The Croatian Prison System and the Protection of Prisoners' Human Rights. Hrvatski ljetopis za kazneno pravo $i$ praksu, 13, 685-743. doi:343.812(497.5)str.685-743.

Barthes, R. (2012). Toward a Psychosociology of Contemporary Food Consumption. In Counihan, C. and Van Esterik, P. (Ed.), Food and culture pp. 37-44. Routledge.

Clemmer, D. (1940). The Prison Community. New Braunfels, TX, US: Christopher Publishing House.

Council of Europe (2016a). Report to the Government of Bosnia and Herzegovina on the Visit to Bosnia and Herzegovina carried out by the European Committee for the Prevention of Torture and Inhuman or Degrading Treatment or Punishment (CPT). https://rm.coe.int/pdf/ 1680760883. Accessed: 27 June 2019.

Council of Europe (2016b). Report to the Government of Serbia on the Visit to Serbia carried out by the European Committee for the Prevention of Torture and Inhuman or Degrading Treatment or Punishment (CPT). https://rm. coe.int/1680697c94. Accessed: 27 June 2019.

Council of Europe (2018a). Report to the Croatian Government on the Visit to Croatia carried out by the European Committee for the Prevention of Torture and Inhuman or Degrading Treatment or Punishment (CPT). https : //rm.coe.int/16808e2a0e. Accessed: 27 June 2019.

Council of Europe (2018b). Report to the Government of Serbia on the Visit to Serbia carried out by the European Committee for the Prevention of Torture and Inhuman or Degrading Treatment or Punishment (CPT). https://rm. coe.int/16808b5ee7. Accessed: 27 June 2019.

Crewe, B. (2009). The Prisoner Society: Power, Adaptation and Social Life in an English Prison. Oxford University Press.

Duda, I. (2017). Svakodnevni Zivot u Obje Jugoslavenske Drzave: Hvatanje koraka s Europom. In Jugoslavija u Istorijskoj Perspektivi pp. 366-382. Helsinški odbor za ljudska prava u Srbiji.

Edwards, J., Hartwell, H., Reeve, W., and Schafheitle, J. (2007). The Diet of Prisoners in England. British Food Journal, 109, 216-232. doi 10.1108/ 00070700710732547. 
Einat, T., and Davidian, M. (2018). "There is no Sincerer Love than the Love of Food" (George Bernard Shaw, 1903): The Meaning of Food and its Uses in Prison Subculture. European Journal of Criminology, 00, 1-20. doi-10. $1177 / 1477370818769258$

Federative Council and Council of Nations of the National Assembly of the Socialist Federal Republic of Yugoslavia (1951). Zakon o Izvrsenju Kazni, Mera Bezbednosti i Vaspitno-Popravnih Mera. http://www.restitucija.gov.rs/doc/oduzeta\%20imovina/pdf/ZAKON\% 200\%20IZVRSEN JU\%20KAZNI \%20MERA\%20BEZBEDNOSTI\%20I\%20VASPITNOPOPRAVNIH\%20MERA_32.pdf. Belgrade, Serbia: Sluzbeni List Federativne Narodne Republike Jugoslavije, 47/51.

Flander, B., and Bucar Rucman, A. (2015). Lost in Transition: Criminal Justice Reforms and the Crises of Legitimacy in Central and Eastern Europe. In Mesko, G. and Tankebe, J. (Ed.), Trust and Legitimacy in Criminal Justice: European Perspectives pp. 111-133. Springer. doi:10.1007/978-3-31909813-5.

Gaes, G. (1994). Prison Crowding Research Reexamined. The Prison Journal, 74, 329-363. doi $10.1177 / 0032855594074003004$.

Godderis, R. (2006). Dinning in: The Symbolic Power of Food in Prison. The Howard Journal, 45, 255-267.

Grofelnik, H. (2014). Terra 1 - Udžbenik iz Geografije za Prvi Razred Gimnazije. Profil, Zagreb.

Hebenton, B., and Spencer, J. (1994). The Contribution and Limitations of Anglo-American Criminology to Understanding Crime in Central-Eastern Europe. European Journal of Crime, Criminal Law and Criminal Justice, 2, 50-61. doi:10.1163/157181794X00043.

Hina (2003). Otvoren novoizgrađeni odjel gospićkog zatvora. https: //www.index.hr/vijesti/clanak/otvoren-novoizgradjeni-odjelgospickog-zatvora/151620.aspx. Accessed: 31 December 2018.

Hina (2017). Sve je manje zatvorenika u hrvatski zatvorima, a evo zbog čega najčešce završavaju iza rešetaka. https://www.vecernji.hr/vijesti/sveje-manje-zatvorenika-u-hrvatskim-zatvorima-a-evo-zbog-ceganajcesce-zavrsavaju-iza-resetaka-1140209. Accessed: 30 December 2018.

Hromadzic, A. (2011). Bathroom Mixing: Youth Negotiate Democratization in Postconflict Bosnia and Herzegovina. PoLAR, 34, 268-289. doi $10.1111 / j$. 1555-2934.2011.01166.x.

HRT Vijesti (2013). Zatvorenici uspjesni stocari. https://vijesti.hrt.hr/ 203599/zatvorenici-uspjesni-stocari. Accessed: 31 December 2018. 
Hrvatski Institut za Povijest, Slavonski Brod (2006). Partizanska $i$ Komunisticka Represija i Zlocini u Hrvatskoj 1944.-1946. Slavonija, Srijem $i$ Baranja. Tiskara Rotim i Market.

Hrvatski Institut za Povijest, Zagreb (2008). Partizanska $i$ Komunisticka Represija $i$ Zlocini u Hrvatskoj 1944.-1946. Zagreb $i$ Sredisnja Hrvatska. Tiskara Rotim i Market.

Jacobs, E., and Mullany, M. (2015). Vitamin D Deficiency and Inadequacy in a Correctional Population. Nutrition, pp. 659-663. doi:10.1016/j.nut.2014. 10.010 .

Jakelic, I. (2003). Lepoglava je u odnosu na Gospic pakao. https: //www.vecernji.hr/vijesti/lepoglava-je-u-odnosu-na-gospicpakao-736645. Accessed: 31 December 2018.

Johnson, R., and Toch, H. (2000). Crime and Punishment: Inside Views. Oxford University Press.

Jones, M. (2017). Eating behind Bars: On Punishment, Resistance, Policy, and Applied Folkloristics. Journal of Academic Folklore, 130, 72-108. doi 10 . 5406/jamerfolk.130.515.0072.

Kendel Jovanovic, G., Pavicic Zezelj, S., Radeta, A., and Linsak, Z. (2010). Quality Food in Prison in Rijeka is Graded Using the Index of a Healthy Diet. In 2nd Croatian Congress on Preventive Medicine and Health Promotion.

Klix (2016). Kako zive zatvorenici u KPZ Zenica. https://www.zenicablog. com/kako-zive-zatvorenici-u-kpz-zenica/, Accessed: 12 February 2019.

Maloca, M. (2017). Jeza i Uzbudenje: Proveli smo dan u bjelovarskom zatvoru; zivot iza resetaka nije daleko od filmskih prikaza. https://epodravina. hr/foto-jeza-uzbudenje-proveli-smo-dan-bjelovarskom-zatvoruzivot-iza-resetaka-nije-daleko-filmskih-prikaza/. Accessed: 05 January 2019.

Martinovic, R. (2012). Provjerili smo kako je u hrvatskim zatvorima - Sto zatvorenika ocekuje iza resetaka? https://www.dnevno.hr/vijesti/ hrvatska/provjerili-smo-kako-je-u-hrvatskim-zatvorima-stozatvorenika-ocekuje-iza-resetaka-70007/. Accessed: 05 January 2019.

Mazower, M. (2000). The Balkans. Phoenix Press.

McCleery, R. (1960). Communication Patterns as Bases of Systems of Authority and Power. Theoretical Studies in Social Organization of the Prison, 15, $49-77$

M.D. (2015). Faktor.ba u posjeti KPZ-u u Banjoj Luci: Zatvorenici najvise kupuju cokolade. https://www.faktor.ba/vijest/faktor-ba-u-posjetikpz-u-u-banjoj-luci-zatvorenici-najvise-kupuju-cokolade-212656. Accessed: 30 December 2018. 
Mesko, G., and Eman, K. (2015). Legitimacy of Policing in Central and Eastern Europe: Results from a Cross-National Law Student Survey. In Mesko, G. and Tankebe, J. (Ed.), Trust and Legitimacy in Criminal Justice: European Perspectives pp. 231-260. Springer. doi:10.1007/978-3-319-09813-5.

Mesko, G., Vosnjak, L., Muratbegovic, E., Budimlic, M., Bren, M., and Kury, H. (2012). Fear of Crime in Urban Neighbourhoods: A Comparative Analysis of Six Capitals. Varstvoslovje, Journal of Criminal Justice and Security, 14, $397-421$.

Ministry of Justice of Bosnia and Herzegovina, Republic of Srpska (2018). Zakon o Izvrsenju Krivicnih i Prekrsajnih Sankcija Republike Srpske. https://www . paragraf .ba/propisi/republika-srpska/zakon-oizvrsenju-krivicnih-sankcija-republike-srpske.html. Banja Luka; Sarajevo, BIH: Sl. glasnik RS, 63/2018.

Ministry of Justice of the Republic of Croatia (2010a). Pravilnik o Kucnom Redu u Zatvorima za Izvrsavanje Istraznog Zatvora. https://narodne-novine.

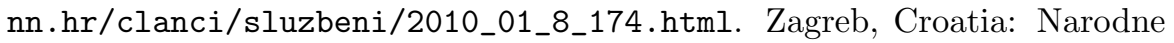
Novine, NN 8/2010.

Ministry of Justice of the Republic of Croatia (2010b). Zakon o Izvrsavanju Kazne Zatvora. https://www.zakon.hr/z/179/Zakon-o-izvrsavanjukazne-zatvora

Ministry of Justice of the Republic of Croatia (2018). Prirucnik za Zatvorenike. https://pravosudje.gov.hr/UserDocsImages/dokumenti/ Zatvorski\%20sustav/Priru\%C4\%8Dnik\%20za\%20zatvorenike\%202018.pdf.

Ministry of Justice of the Republic of Serbia (2014). Zakon o Izvrsenju Krivicnih Sankcija. https://www.paragraf.rs/propisi/zakon_ o_izvrsenju_krivicnih_sankcija.html. Belgrade, Serbia: Sl. glasnik RS, $55 / 2014$.

Ministry of Justice of the Republic of Srpska (2018). Osnovne Informacije o Ishrani u Kazneno-popravnim Ustanovama u Republici Srpskoj. Private communication, e-mail.

Ministry of Justice, Public Administration and Local Self-Government, and Ministry of Health of the Republic of Croatia (2002). Pravilnik o Standardima Smjestaja i Prehrane Zatvorenika. https://narodnenovine.nn.hr/clanci/sluzbeni/2002_08_92_1496.html. Zagreb, Croatia: Narodne Novine, NN 92/2002.

Nesic, A. (2014a). Zatvorska Prica: CZ - Kocka. https://zatvorskaprica. wordpress.com/ Accessed: 30 December 2018.

Nesic, A. (2014b). Zatvorska Prica: CZ - Kuca gladnih. https:// zatvorskaprica.wordpress.com/. Accessed: 30 December 2018. 
Nesic, A. (2014c). Zatvorska Prica: CZ - Shopping. https://zatvorskaprica. wordpress.com/. Accessed: 29 December 2018.

Nesic, A. (2014d). Zatvorska Prica: CZ - Zatvorski recepti. https:// zatvorskaprica.wordpress.com/. Accessed: 29 December 2018.

Nesic, A. (2016). Zatvorska Prica: CZ - Kompleksi. https://zatvorskaprica. wordpress.com/. Accessed: 29 December 2018.

Saric, L. (2004). Balkan Identity: Changing Self-images of the South Slavs. Journal of Multilingual and Multicultural Development, 25, 389-407. doi:10. 1080/01434630408668914

Selih, A. (2012). Crime and Crime Control in Transition Countries. In Selih, A. and Zavrsnik, A. (Ed.), Crime and Transition in Central and Eastern Europe pp. 3-34. Springer.

Smoyer, A. (2019). Food in correctional facilities: A scoping review. Appetite, 141, 1-8. doi $10.1016 / j$.appet.2019.06.004.

Smoyer, A. B., and Kjaer Minke, L. (2015). Food Systems in Correctional Settings: A Literature Review and Case Study. World Health Organization, Regional Office for Europe.

Smoyer, A. B., and Lopes, G. (2017). Hungry on the Inside: Prison Food as Concrete and Symbolic Punishment in a Women's Prison. Punishment and Society, 19, 240-255. doi 10.1177/1462474516665605.

Soher, L. (2016). Procjena Energetske Vrijednost i Nutritivnog Sastava Jelovnika u Kaznionici u Lepoglavi. Caloric Value and Nutritional Composition Assessment of Menus in Lepoglava Penitentiary. Master's thesis University Josip Juraj Strossmayer in Osijek, Faculty of Food Technology Osijek.

Spadijer-Dzinic, J., Pavicevic, O., and Simeunovic-Patic, B. (2009). Zena u Zatvoru - Deprivacije zatvorenickog zivota. Women in Prison - Deprivations of Prison Life. Sociologija, LI, 225-246. doi 10.2298/SOC0903225S

Spasenic, B. (2016). Dok poljoprivreda na slobodi propada: Zatvorske farme u RS-u ostvarile vise od $140.000 \mathrm{KM}$ prihoda. https://www.faktor.ba/ vijest/dok-poljoprivreda-na-slobodi-propada-zatvorske-farme-urs-u-ostvarile-vie-od-140-000-km-prihoda-221814. Accessed: 31 December 2018.

Stajcic, N. (2013). Understanding Culture: Food as a Means of Communication. Hemispheres, pp. 5-14.

Sykes, G. (1958). The Society of Captives: A Study of a Maximum Security Prison. Princeton University Press.

Tewksbury, R. (2006). Behind Bars: Readings on Prison Culture. Prentice Hall. 
The Government of the Republic of Croatia (2017). Izvjesce o Stanju i Radu Kaznionica, Zatvora i Odgojnih Zavoda za 2016. Godinu The Government of the Republic of Croatia.

Toch, H. (1990). The Good Old Days in the Joint. The Prison Journal, 70, 1-8. doi:10.1177/003288559007000102.

Transparency International (2018). Corruption Perceptions Index. https:// www.transparency.org/research/cpi. Accessed: 02 June 2019.

Trkanjec, Z. (2005). Gablec nas svagdasnji. https://www.jutarnji.hr/ arhiva/gablec-nas-svagdasnji/4024170/. Accessed: 12 February 2019.

Ugelvik, T. (2011). The Hidden Food: Mealtime Resistance and Identity Work in a Norwegian Prison. Punishment and Society, 13, 47-63. doi 10.1177/ 1462474510385630 .

Vidic, M. (2009). Kad se ugase svetla. https://www.vreme.com/cms/view. php?id=835431. Accessed: 05 January 2019.

Vlahovic, S., and Galovic, R. (2015). Izvrsavanje Istraznog Zatvora: normativni okvir i praksa u svjetlu zastite temeljnih ljudskih prava. Pravnik: casopis za pravna $i$ drustvena pitanja, 47, 37-58. doi:343.132:342.7.

Volcic, Z. (2013). Connecting the Disconnected: Balkan Culture Studies. Communication and Critical/Cultural Studies, 10, 333-339. doi10.1080/ 14791420.2013.812597.

World Prison Brief (2018). World Prison Brief Data. http://www. prisonstudies.org/map/europe. Accessed: 12 February 2019.

Zilic, A. (2017). U zatvoru Kula u Istocnom Sarajevu trenutno se nalazi 21 zena, iza resetaka najcesce zavrsavaju zbog ubistva. https://www.klix.ba/vijesti/bih/u-zatvoru-kula-u-istocnomsarajevu-trenutno-se-nalazi-21-zena-iza-resetaka-najcescezavrsavaju-zbog-ubistva/170726025. Accessed: 05 January 2019. 